\title{
Humanitarian DNA Identification in Post-Apartheid South Africa
}

To appear in: Keith Wailoo, Alondra Nelson, and Catherine Lee (eds.), Genetics and the Unsettled Past: The Collision between DNA, Race, and History (New Brunswick, NJ: Rutgers University Press, in press)

\author{
Jay D. Aronson ${ }^{1}$ \\ Associate Professor of Science, Technology, and Society \\ Department of History \\ Carnegie Mellon University \\ aronson@andrew.cmu.edu
}

July 29, 2010

\section{Introduction}

This chapter focuses on the convergence of DNA and history in the context of postapartheid South Africa. It examines the relationship between the recent use of forensic DNA profiling to identify missing and disappeared (primarily black) political activists from the apartheid era, and continuing debates over the history of the anti-apartheid struggle from elite and non-elite perspectives. It also foregrounds issues of identity in a country struggling to come to terms with its past. I begin with a general overview of the issues associated with the identification process in the post-apartheid era. I then focus in detail on two specific cases, that of the "Mamelodi 4" and the "Mamelodi 10," in order to illustrate the complexity and ambiguity of the use of DNA identification to clarify history, and perform political work, in the new South Africa. In this story, DNA is not being used to define the boundaries of race, or to trace the

\footnotetext{
${ }^{1}$ This work has been supported by a grant from the U.S. National Institutes of Health's Ethical, Legal, and Social Implications of Human Genomic Research (ELSI) Program, R03 HG004655, 'DNA Identification in the Aftermath of Genocide and Mass Violence.' The human subjects protection procedures practiced by the author have been reviewed and approved by Carnegie Mellon University's IRB (Project ID: HS09-076 Date: 20 February 2009). The author wishes to thank the South African Missing Persons Task Team and Khulumani Support Group for logistical assistance, and, most importantly, the relatives of the missing and disappeared who welcomed me into the their community and their homes and shared their harrowing stories with me.
} 
origins of a particular group of people, but rather to ameliorate past injustices to a historically marginalized group defined entirely by race.

I argue that the families of the missing in South Africa, and especially those whose loved ones were affiliated with the armed struggle against apartheid, are seeking to recover more than just mortal remains in their quest to locate and rebury their missing loved ones. They are also seeking to restore the social, political, and historical identity of their loved ones. In other words, the process of post-conflict DNA identification involves multiple forms of recognition. ${ }^{2}$ First, there is the kind of biological recognition that comes when the mortal remains of the individual are located and then identified by DNA or other forensic methods. Second, families want to recover the social identity of the person identified by scientists and investigators - they want to reclaim them as their flesh and blood and provide them with the proper burial they had lacked for so long. Finally, they seek collective social recognition of the heroic sacrifice that their loved one made for what they believe to be the freedom of all South Africans. Providing this third kind of social recognition means going far beyond the actual DNA identification process to ensuring appropriate commemoration of the life of the formerly missing person. Thus, any effort to identify the missing must simultaneously integrate biological, social, and historical aspects of personhood.

\section{Background}

There are as many as 2000 known missing people from the apartheid era in South Africa, the majority of which are associated with the intensification of the government's repression of

\footnotetext{
${ }^{2}$ Although my own understanding of the situation in South Africa was developed before I read the work of Sarah Wagner on the identification of the missing in the aftermath of Srebrenica, I have adopted her use of the term "recognition" because it properly describes identity as something that is actively constructed through a particular social process rather than something that exists in a static form (Wagner 2008, 10).
} 
blacks in the 1970s and 1980s. During this period, military units and police organizations were willing to kill individuals if they were deemed to threaten national security or the authority of the National Party, which were for all intents and purposes seen to be one in the same. ${ }^{3}$ At the same time, many politically active individuals went into exile and did not return to South Africa once democracy was restored in 1994 (either because they died or started new lives elsewhere).

The exact number of deaths attributable to death squads is disputed, but estimates put the number as high as $1000 .^{4}$ According to one scholar of South African death squads, in the aftermath of the 1976 Soweto Revolt, the apartheid government had adopted murder as a "conscious element of internal security policy." 5 This cold-blooded killing was first conducted by state operatives, and then in the twilight years of apartheid (1985-93) by hired vigilantes of all colors and creeds. ${ }^{6}$ Although families were often able to retrieve the remains of their loved ones after death, in many cases bodies were either buried in unmarked graves or mutilated beyond recognition. ${ }^{7}$ Many members of the armed wings of the major liberation groups, as well as politically unaffiliated individuals, met this fate.

Almost all Southern African ethnic groups — even those that have been Christianizedbelieve that there is a strong and continuous relationship between the living and the dead. ${ }^{8}$ Appropriate burial rituals must be performed in order to ensure that the recently deceased individual is able to take their place as an ancestor (ibid.). When these rituals are not performed,

\footnotetext{
${ }^{3}$ Gottschalk 2002; Pauw 1997; TRC Final Report 1998-2003, volume 2. It is important to recognize that the number of people killed by security forces in South Africa was much lower than in similar conflicts around the world. In other words, apartheid was characterized more by "everyday oppression" as opposed to systematic, extreme violence.

${ }^{4}$ Gottschalk 2002, 231

5 ibid., 234. In numerous personal communications, Madeleine Fullard has downplayed the overall significance of extreme violence in the apartheid system. For her, political oppression, everyday harassment, and economic servitude played an equal, if not greater, role in the injustice of apartheid.

${ }^{6}$ Ibid.

${ }^{7}$ Gottschalk 2002; TRC Final Report 1998-2003, volume 2

${ }^{8}$ Dennie 1996; Eppel 2006; Sundkler 1948
} 
all but the most devoutly Christian Africans believe that the deceased will be forced to wander the nether world between the land of the living and the ancestral homeland. This liminal state both robs the deceased of rest and comfort, and denies the living the protection and counsel that they normally receive from their ancestors. In this situation, the living are thought to be more susceptible to death, disease, economic misfortunate, and bad luck. Because the worlds of the living and the dead intertwine, serious problems emerge when the appropriate rituals are not performed. Further, although not universal among all Southern African cultures, in most it is desirable for the body of the deceased to be buried near where he or she was born in order to ensure easy communication between the living and their ancestors. At a more socio-political level, the presence of the graves of relatives reinforced the claims of the living relatives to belong to, and in, a particular place. ${ }^{9}$

Efforts to locate the missing began during the investigatory phase of the Truth and Reconciliation Commission (TRC), which lasted from 1996-1998. At the end of the hearings, the TRC officially declared 477 people missing, with the vast majority hailing from African National Congress membership, and especially its military wing, Umkhonto we Sizwe (MK). This situation arose for main reasons, including: the fact that the TRC was mandated to deal only with human rights violations that were explicitly political in nature; because the ANC suffered very heavy losses during the struggle compared to most other political groups; and also because ANC members were mobilized to give testimony at a higher rate than many other subgroups within South African society. ${ }^{10}$ Since the initial effort to collect the names of the missing at the TRC, civil society organizations such as the Centre for the Study of Violence and Reconciliation (CSVR) and the Khulumani Support Group, have documented more than 1500 additional cases,

\footnotetext{
${ }^{9}$ Ibid.

${ }^{10}$ Hamber, Nageng, and O’Malley 2000
} 
many of whom had no direct ties to the ANC. Although it is beyond the scope of this chapter, disputes have emerged among various parties over which categories of disappearances ought to be investigated by the government. ${ }^{11}$

Although only a few graves were exhumed by the TRC, the commission recommended that a team be formed within the NPA to continue the work. Because of her own interest in the subject, and interactions with victims and survivors of the apartheid era, former TRC historian Madeleine Fullard began lobbying government officials to create a team to resolve cases involving missing people. ${ }^{12}$ President Thabo Mbeki backed this move in 2003, and the NPA's Missing Persons Task Team (MPTT) has been working to resolve this situation ever since. To date, the MPTT has exhumed more than 64 individuals, approximately 40 of whom have been positively identified at the individual level using DNA and/or other forensic techniques and returned to their families. ${ }^{13}$

\section{The Mamelodi 4}

One of the MPTT's most compelling successes is that of the identification of the "Mamelodi 4." The Mamelodi 4 represent two separate cases. The first incident, which took place in July 1987, South African Police Service's Security Branch (based at the infamous Vlakplaas farm outside Pretoria) first abducted Jackson Maake, who was at the time working as an informant for the security police, after they came to believe that he was a double agent who used his state-provided car to bring weapons into the country for use by the MK. ${ }^{14}$ Maake initially denied the accusation, but under heavy torture he admitted to being a spy and also

\footnotetext{
${ }^{11}$ Cite my article on this subject when it becomes available.

${ }^{12}$ Dewhirst 2008; Fullard 2008.

${ }^{13}$ MPTT, 2008

${ }^{14}$ van Vuuren 1996, 343
} 
confessed that he was involved in a plot to bomb the police's offices in the area. ${ }^{15}$ He then gave his interrogators Andrew Makupe's name as his contact with the highly secretive MK. ${ }^{16}$ Makupe was then brought to the same location, and after being subjected to torture, he revealed that his job was to bring arms into the country and gave Harold Sefolo's name as his leader within the MK. ${ }^{17}$ Sefolo was then brought to the scene (after Makupe, also Sefolo's friend and business partner, was forced to telephone him to tell him to trust the people who were coming to pick him up) so that the police could obtain more information about the ANC cells in the region. In order to compel Sefolo to provide more information, the police shoved a knife up his nose and ultimately electrocuted Maake and Makupe to death in front of him. According to his interrogators, he would not divulge any important information, and eventually asked them to kill him. First, though, he was granted the opportunity to sing N'Kosi Sikelea Afrika (the song of resistance that is now South Africa's national anthem) at his request. ${ }^{18}$ Once dead, the security officers cut off the hands of the three men (so that they could not be identified by fingerprinting) and then piled their bodies on top of a land mine. They were then blown to bits in an attempt to make them unrecognizable. ${ }^{19}$ The stated justification for the killing was that the identity of the interrogators, and the information gained during the interrogation, had to be protected..$^{20}$

In a separate incident, Justice Mbizana, also from Mamelodi and a known member of an MK unit based out of Swaziland, was arrested by security police soon after returning to the country after a period of exile. He was then taken to an isolated farm where he was interrogated and tortured for more than a week. ${ }^{21}$ During the course of this process, he was prodded with a

\footnotetext{
${ }^{15}$ Ibid., 344

${ }^{16}$ Ibid., 356

${ }^{17}$ Ibid., 350

${ }^{18}$ Ibid., 351

${ }^{19}$ Ibid., 353

${ }^{20}$ Ibid., 356

${ }^{21}$ Prinsloo 1999
} 
burning $\log$ in the head and (possibly) the anus, shot at close range, drugged with an overdose of sleeping medication, and then finally bludgeoned to death with a gardening spade. He too was blown up using land mines to destroy the evidence of wrong-doing and to prevent his comrades of knowing what happened to him. The remains of the four men were buried together by chance in a single casket in a pauper's cemetery at Winterveld because they happened to show up in the morgue on the same day. ${ }^{22}$

The TRC amnesty hearings, and simultaneous criminal prosecutions of perpetrators who did not qualify for amnesty, provided relatives of the Mamelodi 4 with their first opportunity to find out what happened to their loved ones. Subsequently, Elizabeth Maake (Jackson's mother), Lizzie Thandi Sefolo (Harold's wife) and Mabel Matlakala Makope (Andrew's wife) testified before the TRC's Human Rights Violations committee (HRVC). In addition to recounting their stories and their suffering, the women made several demands, most importantly: providing them with information about their missing loved ones and the opportunity to visit the sites that were relevant to the death of their loved ones; helping the families locate the bodies of the Mamelodi 4 so they could be properly buried; and also holding the perpetrators accountable for their actions to the extent that was possible under the mandate of the TRC. ${ }^{23}$ As Elizabeth Maake testified:

I would...like to rebury him so that we can also be able to go to the cemetery, to the grave of our loved one like other people. We don't know if it's really true that they killed him. We don't know if he's alive or dead. We just heard that he's dead. We would really like to know the truth and we would also like to see where he died. [The police officials involved] must show us where he is. We would also like to request his remains

\footnotetext{
${ }^{22}$ Bateman 2007; Smillie 2007

${ }^{23}$ Make 1996; Makope 1996; Sefolo 1996
} 
so that we can bury him in our graveyard. That's the thing we would really like to request from you, from the Truth Commission. ${ }^{24}$

All three women spoke in some detail about the fruitless efforts they undertook to find out what happened to the three men, and the extent to which the lack of information was as painful for them as the absence of their loved ones. Not knowing prevented them from moving on with their lives and fulfilling their duties toward their remaining family members and their community. This testimony resonates with the experiences of families of the missing in other parts of the world. In her book on DNA identification in the aftermath of the Srebrenica massacre, for instance, Sarah Wagner describes in detail the insufficiency of the notion of a "missing person," and the idea that they are probably dead. She writes that such knowledge is incomplete and hollow for families of individuals who have disappeared: "the term missing signals the absence of a story, a personal history yet untold, for each victim." Further, the term itself intensifies the anguish associated with loss - it reminds of them of the heinous physical violation of their relatives' remains. ${ }^{25}$

After testifying at the TRC in 1996, the families of the Mamelodi 4 heard nothing more about the fates of their loved ones for nearly a decade. Thanks to the amnesty hearings, in which the security police who were responsible for the deaths of the Mamelodi 4 told the TRC how and why they were killed in exchange for amnesty from punishment, the families at least knew generally what happened to their loved ones, but they did not know how much of it was true and they still had no way of retrieving the bodies for proper reburial.

Then, in 2005, the Mamelodi 4 families were contacted by Madeleine Fullard to let them know that the MPTT was going to investigate the case. Through a combination of archival

\footnotetext{
${ }^{24}$ Maake 1996, 2

${ }^{25}$ Wagner 2008, 7
} 
research and archaeological investigations, the grave that contained the remains of the Mamelodi 4 was located in the pauper's section of Winterveld Cemetery, in the outskirts of the Pretoria townships. ${ }^{26}$ The possibility of individual identification looked dire when the MPTT opened up the graves and found a mass of charred, comingled bones in a decaying coffin. Once the remains were sorted out, MPTT investigators realized they had only a few charred hip and leg bones to work with. Fullard sent the materials to the Human Identity Laboratory at the University of Western Cape, which had personnel who had been trained to extract DNA from ancient bone fragments and had an ongoing collaboration with a leader in this field from Sweden. ${ }^{27}$

Ultimately, the laboratory was able to extract DNA from the bones and individually identified the four men by comparing their DNA profiles to living relatives. ${ }^{28}$ After the identifications were made, the Mamelodi 4 received the remains of their loved ones at a ceremony at Freedom Park in Pretoria (a monument to all freedom fighters in South Africa, including those Afrikaners who fought against British imperial rule) and reburied them at the local cemetery near their homes in Mamelodi.

Early on in my research, I assumed that this case was an exciting example of how science could be used could resolve historical questions in a racially and politically charged atmosphere, and also bring peace and closure to family members of the disappeared. When I arrived in Mamelodi to meet with relatives of the Mamelodi 4 in May 2007, I expected to be greeted by relieved mothers and wives who had finally achieved some measure of justice and comfort after nearly twenty years of uncertainty. Instead, I was confronted by angry women who had been freshly wounded by the identification and reburial process. I was quite frankly shocked, but over the course of the time that I spent with them, the source of their anger became understandable to

\footnotetext{
${ }^{26}$ Fullard 2007

${ }^{27}$ Laet 2008

${ }^{28}$ Davison, Benjeddou \& D’Amato 2008
} 
me. To fully appreciate their claims, however, requires a brief detour into the complex dynamics of the anti-apartheid movement, with its competing philosophies of liberation, parallel tactical and intelligence operations, personal and organizational rivalries, unresolved class conflicts, and debate about who deserves credit for the emergence of democracy in the country.

\section{The Liberation Struggle}

The ANC is a curious institution, having gone through many forms during the course of its history: a small organization of black elites who demanded citizenship (1912-early 1940s); a structured, explicitly multiracial membership organization that focused on change through mass political action (mid-1940s-1960); an officially banned liberation organization whose leaders were either in exile, imprisoned, or operating underground (1960-1989); an unbanned organization with multiple organizational nodes and intense jockeying for power (1990-1994); the chief agent of the negotiated political transition (1991-1994); and finally, with the election of Nelson Mandela in 1994, the dominant political party in what is essentially a one-party state. ${ }^{29}$

The history of the organization is long and complex, but for the purposes of this chapter, it is important to understand that after being banned in 1960, the central leadership of the ANC was dispersed in prisons, exile military bases in bordering countries, and major cities around the world. By the early 1970s, there were two main centers of the ANC in Africa-Lusaka, Zambia and the Robben Island prison, where Mandela, Walter Sisulu, Goven Mbeki (former South African President Thabo Mbeki's father) and others were being held. Each had its own character, style of work, and even understandings about what the struggle against apartheid ought to look like. ${ }^{30}$ Among the first priorities of the wing of ANC exiles in Lusaka was the

\footnotetext{
${ }^{29}$ For a review of the history of the ANC, see: Barrell 1993; Butler 2007; Dubow 2000; Meli 1988 ; Suttner 2007.

${ }^{30}$ Suttner 2002
} 
creation of a military wing, called Umkhonto we Sizwe (MK, translated as "Spear of the Nation") that would eventually lead black South Africans in armed overthrow of the apartheid state. Beginning in the late 1970s, the ANC also sought to establish a network of underground cells within South Africa that could be mobilized as necessary to carry out covert action, and ultimately armed insurrection under the leadership of MK forces. Paralleling this development, the Pan-African Congress, a group that had broken away from the ANC in 1959 because it believed that Africans should not collaborate with Whites, Coloureds, and Indians in the liberation struggle, formed the Azanian People's Liberation Army (APLA) to foment armed insurrection against the apartheid state. Making no effort to hide its intentions, APLA adopted the slogan "one settler, one bullet." 11

This militarization produced a general feeling among the ANC membership that nonviolent activities, political negotiations, and mass action would have little role in the return of the country to majority rule. But while the ANC was methodically preparing for its moment of military glory in exile, and also carrying out targeted if largely symbolic attacks against the apartheid state, neither the black population nor the activist community within South Africa were standing idly by waiting for MK forces to liberate them. In fact, the ANC watched much of the liberation struggle take place from the sidelines. Protests flared across the country, most famously in the 1976 Soweto uprising, which began as a peaceful demonstration against Afrikaans-medium schooling for black students before it turned confrontational and bloody when the police moved in to quell the march. In numerous other townships, including Mamelodi, students protested for better education and people of all ages marched for higher quality, more affordable housing. ${ }^{32}$ The 1980s saw heightened mass action within organized labor and civil

\footnotetext{
${ }^{31}$ Heribert and Moodley 1993, 177

${ }^{32}$ Butler 2008
} 
society as well, the goal of which was to "make apartheid unworkable and South Africa ungovernable." ${ }^{33}$ These actions were carried out under the rubric of various labor unions and a domestic umbrella organization called the United Democratic Front. ${ }^{34}$

By the late 1980s, ANC leaders realized that its military strategy was not going to be sufficient to end apartheid, ${ }^{35}$ while the ruling white National Party simultaneously came to the conclusion that, given disturbances in the realms of labor and civil society, it could not systematically separate and dominate the black community forever. ${ }^{36}$ Further, the global recession of the late 1980s and the fall of the Soviet Union (a major financial and ideological supporter of liberation movements around the world) called into question the long-term viability of the ANC in exile. ${ }^{37}$ And finally, through secret discussions between leaders of the state and anti-apartheid forces (most notably involving Nelson Mandela and other ANC members, but also members of the liberal white business community, union leaders, and intellectuals of all ethnic and racial backgrounds) it slowly became clear to most parties that a non-violent solution to the situation in South Africa was not only possible, but desirable. ${ }^{38}$ Although even the most liberal whites certainly did not imagine handing power over to non-whites at any point in the near future, they did recognize that something would have to be done in order to prevent economic devastation and untold violence. ${ }^{39}$ Thus, when the apartheid state unbanned the ANC in 1990, it did so with the understanding that the organization would become its dominant partner in

\footnotetext{
${ }^{33}$ Suttner 2007, 2

${ }^{34}$ Seekings 2000

${ }^{35}$ Cronin 2002; Thompson 2000

${ }^{36}$ Sparks 1989; Thompson 2000

${ }^{37}$ ibid.

${ }^{38}$ Butler 2008; Sparks 1994; Thompson 2000

${ }^{39}$ Butler 2008
} 
reforming the political and social situation in the country in a way that would satisfy the majority non-white population. ${ }^{40}$

The decision to shift the ANC's modus operendi from revolution to negotiation, made by the elite leadership without any real input from the rank and file, ultimately led to a sense of betrayal and anger amongst two groups: the ordinary people who had put up with the indignities of life under apartheid while simultaneously working to undermine it; and those who had dedicated the better part of their adult lives to military training (in often squalid conditions in exile) for the day that they would retake their homeland by force. ${ }^{41}$ This bitterness was heightened the fact that post-independence, the upper echelons of the ANC took positions in the government, the military, finance, and industry, while the rank and file members were sent back to their homes in the townships and rural areas with little or nothing to show for their efforts. Mashike also notes that the shift in tactics left many former MK combatants with the feeling that the skills they had sacrificed so much to acquire were not only irrelevant in the transition to democracy, but also left them with no means of sustaining themselves in the new South Africa. ${ }^{42}$

Thus, while the ANC has a firm grip on political power, it must also address the demands of important constituencies that feel they have not been appropriately recognized and rewarded for their contributions to the struggle. Thus, efforts to identify the missing can be opportunities for the ANC government to "care for" its citizens and establish some sense of control over them, even if they don't directly articulate the latter aim in their official pronouncements. ${ }^{43}$ Indeed, the stated goal of the MPTT is to:

\footnotetext{
${ }^{40}$ deKlerk 1998; Mandela 1994; Sparks 1994; Waldmeir 1997

${ }^{41}$ Mashike 2007; Suttner 2007

${ }^{42}$ Mashike 2007; Mashike 2008; Suttner 2007

${ }^{43}$ Wagner 2008
} 
...offer families some recognition of their plight. This official recognition and devotion of state time and resources to their case is a fundamental step in re-incorporating these 'lost citizens' into the body of post-apartheid South Africa. Listening to their stories, recording the events and recovering documentation forms part of the recognition process and the restoration of dignity to the families and the life of the disappeared person. ${ }^{44}$

It is important to remember that there are three forms of recognition in the context of the identification of missing victims of the apartheid struggle: biological recognition, familial recognition; and communal recognition. The relatives I spoke to said that they were elated when they heard that the MPTT was able to individually identify their remains and that they would finally be able to give their loved ones a culturally appropriate burial. But they told me that the happiness they felt had subsided because of the failure of the local ANC branch to provide what they considered to be an acceptable funeral and commemoration for their loved ones. Their perception proper funereal rights was in large measure political, and based on what they had seen in the first reburial to take place in Mamelodi, that of the well-known ANC/MK figure Reginald Kekana, whose reburial was used by the Department of Justice as the national kick-off for the Missing Persons Task Team. ${ }^{45}$ Indeed, the handover ceremony at Freedom Park was an all-star affair, with full military honors accorded to Kekana, and three other MK operatives whose bodies were recovered at the same time, and a guest list that included prominent politicians, military officials, and famous leaders of the struggle. Kekana was praised as a military hero who

\footnotetext{
${ }^{44}$ Missing Persons Task Team 2006, 20-21

${ }^{45}$ Fullard 2008
} 
died to make his people and his country free from colonial rule. ${ }^{46}$ For Mabel Makope, the honors he received "shows everybody that this guy has fought.",47

All three women told me that they expected the same of the ceremony for their loved ones. But in the end, there was no significant military presence, no pomp and circumstance, not even the mayor of Mamelodi bothered to show up. Makope told me that "it was like we were burying an old person. We are not happy at all. There were no flags. There were no MKs to march for them to show people that these people have fought for this country. It was like a normal funeral."48 For Lizzie Sefolo, the "sickness was removed [when the bodies were initially recovered], but now it's coming back. Because it's like they were not really people who fought for this country, it was just remains. ${ }^{, 49}$ She continued:

It was not proper. No matter, they put some stones, the headstones. That doesn't interest us. We wanted these people to be buried as soldiers and respected as people who fought for this country. We are here now, we are free, because of the people like them. Why [are they] not being respected like others?... So the truth must be said. And then you keep quiet and say 'you mustn't talk about that' and at the end of the day you - it's you who is getting the pain, and you are suffering alone. So they must know that we are not happy at all. ${ }^{50}$

During the course of the discussion, they explained to me that the desire to have their sons and husbands memorialized as military heroes in the armed struggle against apartheid (or, in other words, to give their deaths historical meaning and to make them eligible for state benefits that accrue to family members of people who die in the line of duty), was just as

\footnotetext{
${ }^{46}$ Ntuli 2005

${ }^{47}$ Makope 2007

${ }^{48}$ Makope 2007

${ }^{49}$ Sefolo 2007

${ }^{50}$ Sefolo 2007
} 
important as locating their physical remains through DNA profiling. Simply finding the bones was not enough. The women argued that the ANC elite only truly cared about the missing people who fit into their own self-congratulatory narrative about the downfall of apartheid-i.e., one that privileges the return from exile and Robben Island, along the settlement negotiated by F.W. de Klerk and Nelson Mandela, over the street demonstrations, riots, and acts of civil disobedience by ordinary people that made the country ungovernable for the apartheid state. This interpretation of the current situation was strengthened in their minds by the fact that Kakena had spent a significant amount of time in exile, while their loved ones were primarily internal operators. ${ }^{51}$ Ultimately, the relatives of the Mamelodi 4 that I spoke to were deeply disappointed that the exhumation and identification process did not provide them with an opportunity to clarify history.

The women place the blame squarely on the shoulders of the local ANC branch, which operates largely autonomously from the national ANC organization. Indeed, in his analysis of South African politics after 1994, Lodge states that when ordinary South Africans profess disdain about the state of governance and service delivery in the country, the target of their anger is generally at the regional or local level. ${ }^{52}$ The women told me that the local ANC branch didn't even bother to inform the community that a reburial of formerly missing MK comrades would be taking at the cemetery. While they did pay for proper headstones for the cemetery as noted above (see photo), they did not give the families money to buy food for family members and friends who were taking part in the ceremony. ${ }^{53}$

Delving deeper into the problems with the reburial ceremony, the women told me that there were tension between long-standing members of the ANC and those who had joined more

\footnotetext{
${ }^{51}$ Maake 2007; Makope 2007; Sefolo 2007

${ }^{52}$ Lodge 2002, 33

${ }^{53}$ Maake 2007; Makope 2007; Sefolo 2007
} 
recently for reasons that weren't always grounded in ideology or a shared sense of struggle, which is typical in this organization that had less than 15,000 people in 1990 when it was unbanned, and more than 500,000 by the end of $1991 .^{54}$ Further, one of the women had close family members who were part of the MK Military Veterans Association in Mamelodi (MKMVA). She told me that MVA would have liked to take control of the burial but they felt that the ANC had jurisdiction because of their relationship (however far removed) to the national government. They said that there is now deep regret that they let the ANC handle the reburial.

For the three women, resolution had not yet come at the time that I initially spoke to them in May 2007. They had begun to go to ANC meetings, despite not all of them being members, to demand an explanation for what they perceived as ill-treatment. For them this process was yet another necessary part of the healing process. As one of the women told me, "closure must be there in a proper way... we are still waiting. ${ }^{, 55}$ When I returned to Mamelodi in 2008 and 2009, it was clear to me that while their anger had mellowed somewhat, they still felt that the government had not met its obligations to them as relatives of fallen military veterans.

When I asked Madeline Fullard of the Missing Persons Task Team what went wrong with the Mamelodi 4 handover and reburial, she suggested that the women were perhaps reading too much into the differences between the two funerals that they had witnessed. She explained to me that the Kakena ceremony was part of the government's kick-off for the Missing Persons Task Team, and was meant to be a singular event to raise public awareness for the program and the issue of disappearances more generally. She noted that the Department of Justice's TRC unit was responsible for the handover and the local political party for the reburial, so she was not heavily involved in the planning of the events. In retrospect, she laments that the false

\footnotetext{
${ }^{54}$ Lodge 2002, 33

${ }^{55}$ Sefolo 2007
} 
expectation of such a grand proceeding was created for the Mamelodi families because it is impossible to provide each and every identified person with such an extravagant ceremonyhowever appropriate it would be to do so. "A whole series of acknowledgments should take place," she told me, "but it's going to be a faulty process because it's government, and government generally doesn't fulfill peoples' fantasies at any level."56

\section{Mamelodi 10}

While the case of the Mamelodi 4 illustrates the importance of the commemorative dimension of post-conflict identification, another case from the same community, that of the "Mamelodi 10" provides a window into another, equally crucial part of the process: that the provision of information and access to the physical evidence associated with the deaths of the missing can enable recognition even in the absence of confirmatory DNA test results.

The case of the "Mamelodi 10" (Rooibaard Geldenhuys, Jeremiah Magagula, Steve Makema, Abram Makolane, Samuel Masilel, Kabimi Morries, Jeremiah Ntuli, Thomas Phiri, Elliott Sathekge, and Sipho Sibanyoni; also known as the "Nietverdiend 10" after the site where they were killed) involved ten politically active teenagers from Mamelodi, who were "recruited" in June 1986 by Joe Mamasela, a black security police officer posing as an MK agent, to go into exile with the MK in Botswana to receive military training. En route, the minibus that they were being transported in was ambushed by security forces at a pre-arranged spot. The young men were then ordered off of the bus by the hit squad, who then injected them with tranquilizers to incapacitate them. They were then loaded back into the bus, along with several liters several liters of gasoline, a limpet mine, and an AK-47. The bus was then run into a tree and set alight to

\footnotetext{
${ }^{56}$ Fullard 2008
} 
make it appear as if there had been a road accident. ${ }^{57}$ The heavily charred remains of the ten young men were then taken by the security police to an undertaker who subsequently buried them in pauper's graves at Winterveld Cemetery. It should be noted that this kind of incident was not uncommon in apartheid South Africa, although the remains of the victims were often returned to the families by authorities, such as in the case of the KwaNdeble 9, who were killed under very similar circumstances by Mamesala and colleagues a few weeks later.

Because several former security police applied for amnesty on the Mamelodi 10 case, it fell under the remit of the MPTT, which in 2005 with the help of members of the Argentine Forensic Anthropology Team, succeeded in locating ten bodies believed to belong to the Mamelodi 10 cohort. $^{58}$ Fullard and her colleagues were fairly certain that the remains belonged to the Mamelodi 10 because they were able to locate documentation that confirmed chain of custody from the security police all the way through to burial records at Winterveld. The only complicating factors were that the ten bodies were buried along with four paupers who arrived at the undertaker at around the same time, and that there were some serious discrepancies between the cemetery records and actual burial patterns on the ground. Thus, the team opened several graves that clearly belonged to people other than the Mamelodi 10 victims. Ultimately, though, they did succeed in locating ten bodies that bore the kind of trauma that one would expect in the deaths that these young men faced.

In order to obtain confirmation of the identity of the bodies, Fullard sent bone samples to an American company called Bode Technologies for identification. After nearly a year of hearing nothing, Fullard received what she described for the record as "disappointing" results, ${ }^{59}$

\footnotetext{
${ }^{57}$ Rademeyer 2005.

${ }^{58}$ Missing Persons Task Team 2006

${ }^{59}$ Fullard 2007
} 
which suggested that the ten bodies were unrelated to the families of the Mamelodi $10 .^{60}$ The results created emotional chaos for everyone involved in the process, including members of the MPTT. $^{61}$

Fullard, however, was not convinced that Bode had done all they could to properly analyze the DNA from the Mamelodi 10 samples, so she turned once again to Neil Laet, from the University of Western Cape. Unfortunately, Laet could not generate individual identifications for nine of the ten bodies, although he did convincingly demonstrate that they could not be ruled out as being part of the Mamelodi 10. The news on the tenth body surprised everybody-it was positively excluded as being a member of the Mamelodi 10 (MPTT 2008). This meant that the MPTT would have to continue searching graves in Winterveld Cemetery - as of July 2010, the tenth body has not been found.

Because of the inconclusive DNA results, Fullard asked an American expert on bone trauma named Steve Symes to come to South Africa to examine the presumptive Mamelodi 10 remains. In his analysis, Symes concluded that the nine sets of remains belonged to men in the age range of the Mamelodi 10 and that their condition was consistent with their bodies being subjected to explosives and intense heat. Based on that information, along with the chain of custody records and the presence of a particular type of coffin associated with pauper burials, the MPTT declared that the nine bodies did indeed belong to the Mamelodi 10 and began to make preparations to hand them over to the families. As it became clear that there would be no conclusive individual identification of the Mamelodi 10, and that there was no guarantee that the tenth body would be found anytime soon, the families of the victims decided to bury the nine

\footnotetext{
${ }^{60}$ Missing Persons Task Team 2006, 17

${ }^{61}$ Fullard 2007
} 
bodies together in a shared grave, leaving space for the tenth if and when he was ever recovered. ${ }^{62}$

In a July 2008 interview, the women uniformly stated that they were deeply disappointed that the remains could not be individually identified. However, they all understood the difficulty of extracting DNA from bones that had been subject to the intense heat of the minibus fire and then buried in ground with little protection. Although collective burial was not ideal for the women, it was at least a major improvement over the previous state of affairs for both family members and the deceased. Thus, their overarching goal from the process shifted from hoping for individual identity to ensuring that the located remains were those of the Mamelodi 10 as a collective. As Maria Ntuli, mother of Jeremiah stated: "they have been burned and from that they went to their grave, and in the grave there was no more coffin, they were just lying in the ground there. Now, how can the DNA be there? At my side, I am very satisfied with what they have done for us. Really, I am satisfied. Even my children, I told them that the DNA doesn't come out. It doesn't match to any remains, so the only thing we can do is to bury those remains and get over with it." ${ }^{, 63}$

For Katherine Magagula, mother of Jeremiah Magagula, what was critical for the mothers in the absence of positive DNA results was the information that was carried through all along the investigation of finding the remains was that which gave them hope that these would be the remains of their loved ones. ${ }^{64}$ The MPTT made sure that the women had access to the photographs of the crime scene (which were recovered by the team from security police records), the opportunity to examine the mortuary records, and a detailed understanding of the investigation process from start to finish. At the mothers' request, Fullard also arranged for

\footnotetext{
${ }^{62}$ Ntuli 2008.

${ }^{63}$ Ntuli 2008

${ }^{64}$ Magagula 2008.
} 
Symes to return to South Africa to give the women a presentation on why he felt confident declaring that the remains were those of their children. ${ }^{65}$

One of the most interesting aspects of the bones was the extent to which they were markers of the collective, but not individual, identity of the people who died. This is more in line with the situation in forensic anthropology in the era before widespread use of DNA identification. During one of my meetings with the Mamelodi 10 relatives, there was a long and fascinating discussion about how the women reacted to seeing the bones of their loved ones for the first time-i.e., during the exhumation itself. All of the women who spoke reported that they felt conflicting feelings of curiosity, anxiety and even excitement to see human remains on the one hand, and almost indescribable pain and heartache on the other. It is interesting to note that this emphasis on bones is quite different than the situation in the former Yugoslavia, where ICMP case managers discourage viewing of bones because they "offer no visible link to the image that family members have of the person in the final moments at the fall of the enclave." In the Balkan context, much more emphasis is placed on the personal effects recovered with bodies. $^{67}$

At yet another level, Lizzie Sefolo, wife of Harold from the Mamelodi 4, said that witnessing the exhumation was a kind of validation of the process of identification, that they were a part of the investigation rather just being recipients of information. She said that the relatives are able to follow the entire process through to see exactly how investigators deal with particular remains and when you find them. She noted that there is always the possibility of the remains in question not being the ones you are looking for. For the women, watching the actual exhumation and initial investigation gave them a sense of "how you prove or disprove of the

\footnotetext{
${ }^{65}$ Magagula 2008, Ntuli 2008.

${ }^{66}$ Wagner 2008, 145

${ }^{67}$ Ibid.
} 
identity." ${ }^{98}$ Sefolo concluded that watching gave them a sense that exhumations are long, involved processes, and "not just digging." ${ }^{, 99}$ Another woman went further, suggesting that had they not actually gone to the gravesite to witness the exhumation, they would have had serious doubts about the veracity of the MPTT's findings. ${ }^{70}$

Thus, we can see that at least in the case of the women from Mamelodi, being present at the exhumation and gaining access to all relevant information about the events leading to the deaths of their loved ones, fulfilled two important purposes. The first was to help them bring the period of uncertainty in their lives to a close by given them the knowledge they lacked for so long. This, of course, is not a new phenomenon. The presence of families at exhumations was is key component of the Argentine Forensic Anthropology Team's protocol and, as a result, has been widely adopted by forensic teams in subsequent investigations throughout Latin America. ${ }^{71}$

Secondly, the exchange of information between the investigators and the relatives of the missing helped them recognized the burnt and degraded remains as their own. They came to understand the process used to confirm identity and to trust the scientists and investigators doing the work. While the outcome was obviously not as satisfying as it would have been if individual identification would have been possible though DNA identification, the fact that the bodies were recovered seems to have gone a long way to ameliorating the pain and uncertainty that they felt. Even the Mamelodi 4 relatives, who were deeply dissatisfied by the memorialization efforts for their loved ones, still fully accepted, and were grateful for, the work done by the MPTT. ${ }^{72}$

\footnotetext{
${ }^{68}$ Sefolo 2008

${ }^{69}$ Ibid.

${ }^{70}$ This statement was made during a group discussion in Mamelodi in July 2008 — upon listenting to the recordings, I could not determine exactly who expressed this view, but it is clear that the other relatives in the room at the time agreed.

${ }^{71}$ Sanford 2003

${ }^{72}$ Maake 2007; Makope 2007; Sefolo 2007
} 
Once again this brings us back to the issue of commemoration and memorialization - the third form of recognition. The mothers of the Mamelodi 10 were very adamant that they wanted to have a better experience than the Mamelodi 4 victims, one that was dignified and in accordance with the sacrifice that they believed their children had made for the country. The Mamelodi 4 relatives felt the same way. Indeed, Lizzie Sefolo declared that the families of the 4 were going to work with the Mamelodi 10 mothers to ensure that they would have a better experience. $^{73}$

Their efforts were on the surface quite successful, as the Mamelodi 10 reburial that was far more reminiscent of Reginald Kakena's than the Mamelodi 4's. Indeed, along with speeches from religious figures and MKMVA officials, their ceremony included appearances by the mayor of Tshwane (the administrative district including Pretoria and its former townships) and the premier of Gauteng state, as well as a tribute from Kgalema Motlanthe, the interim President of the country (who took over from the recently deposed Thabo Mbeki). ${ }^{74}$ Thus, the Mamelodi 10 succeeded in using the occasion of their of their loved ones remains in order to insert their loved ones into the history of the new South Africa in a way that the more passive Mamelodi 4 families had not.

Yet, they were still deeply unhappy with the process by which their loved ones were buried for the same reasons that the Mamelodi 4 were, namely the failure of the ANC to follow through with their obligations to fallen military veterans. Specifically, the ANC did not provide the women with the food that they were required to serve to relatives at a funeral, and they did not provide the coffins that were to be used to bury the remains of the Mamelodi 10. Instead, the MKMVA had to arrange donations of coffins from local undertakers. While such complaints

\footnotetext{
${ }^{73}$ Sefolo 2008

${ }^{74}$ MKMVA 2008b
} 
may seem trivial, it is important to remember that the women I spoke to care deeply about the symbolic actions of the government that is supposed to represent them.

\section{Conclusion}

In her work on the identification of the missing in Bosnia, Sarah Wagner notes that the "path leading from the unrecognized to the recognized also forces open the term identity. Identity not only signifies the relationship between a name and a set of physical remains but also encompasses the social ties that bind a person to a place, a time, and, most importantly, to other human beings."75 From my analysis of the situation in post-apartheid South Africa, it is clear that DNA identification clearly facilitates the process of biological recognition, but it does little to ensure that family members recognize the loved ones that they lost so long ago as social beings, or that society at large will recognize the recently recovered individuals as military heroes in the struggle against apartheid. But history, of course, does not write itself. To achieve the kind of social recognition that is so crucial to relatives of missing MK operatives, serious political work must be undertaken alongside of DNA identification. Thus, DNA identification provides the opportunity to produce some sense of closure for families of the disappeared, rather than closure itself.

\footnotetext{
${ }^{75}$ Wagner 2008, 11
} 


\section{Bibliography}

Barrell, Howard. "Conscripts to Their Age: African National Congress Operational Strategy, 1976-1986." Ph.D. Thesis. Oxford University, 1993.

Bloch, Maurice, and Jonathan Parry. "Introduction: Death and the Regeneration of Life." In Death and the Regeneration of Life, edited by Maurice Bloch and Jonathan Parry, 1-44. Cambridge: Cambridge University Press, 1982.

Butler, Anthony. Cyril Ramaphosa. Johannesburg: Jacana Books, 2008.

-. "The State of the African National Conference." In State of the Nation: South Africa, edited by Sakhela Buhlungu, John Daniel, Roger Southall and Jessica Lutchman, 35-51. Cape Town: HSRC Press, 2007.

Commission, Truth and Reconciliation. "Final Report." Cape Town: Juta and Co., 1998-2003.

Davison, Sean, Mongi Benjedou, and Maria Eugenia D'Amato. "Molecular Genetic Identification of Skeletal Remains of Apartheid Activists in South Africa." African Journal of Biotechnology 7, no. 25 (2008): 4750-57.

de Klerk, F.W. The Last Trek--a New Beginning: The Autobiography. Basingstoke: Macmillan, 1998.

Dennie, Garry Michael. "The Cultural Politics of Burial in South Africa, 1884-1990." Ph.D., Johns Hopkins University, 1996.

Development, Department of Justice and Constitutional. "Notice 1539 of 2008, Invitation to Submit Comments on Proposed Exhumation Policy on Cases Reported to the Trc." Government Gazette 31723 (2008): 3-17.

Dewhirst, Polly. "Transitional Justice and Disappearances, a Briefing Paper." International Center for Transitional Justice, 2008.

Dubow, Saul. The African National Congress. New York: Sutton Publishing, 2000.

Eppel, Shari. "'Healing the Dead': Exhumation and Reburial as Truth-Telling and PeaceBuilding Activities in Rural Zimbabwe." In Telling the Truths: Truth Telling and Peace Building in Post- Conflict Societies, edited by Tristan Anne Borer, 259-88. Notre Dame, IN: University of Notre Dame Press, 2006.

Fullard, Madeleine. Personal Interview with Author. Cape Town, South Africa, May 2007.

Fullard, Madeleine. Personal Interview with Author. Pretoria, South Africa, June 2008.

Gottschalk, Keith. "The Rise and Fall of Apartheid's Death Squads, 1969-93." In Death Squads in Global Perspective: Murder with Deniability, edited by Bruce B. Campbell and Arthur D. Brenner, 229-60. London: Macmillan, 2002. 
Hamber, Brandon, Dineo Nageng, and Gabriel O'Malley. "'Telling It Like It Is.' Understanding the Truth and Reconcilliation Commission from the Perspective of Survivors." Psychology in Society 26 (2000): 18-42.

Hamber, Brandon, and Richard Wilson. "Symbolic Closure through Memory, Reparation and Revenge in Post-Conflict Societies." Journal of Human Rights 1, no. 1 (2002): 35-53.

Heribert, Adam, and Kogila Moodley. The Opening of the Apartheid Mind: Options for the New South Africa. Berkeley: University of California Press, 1993.

Laet, Neil. Personal Interview with Author. Cape Town, South Africa, July 2008.

Lawyers for Human Rights,. "Proceedings from a Conference on the International Convention for the Protection of All Persons from Enforced Disappearances: Implications for South Africa and the Region." Pretoria: Lawyers for Human Rights, 2008.

Maake, Elizabeth. Testimony before the Truth and Reconciliation Commission Human Rights Violations Committee, Johannesburg, 30 April 1996.

Maake, Elizabeth. Personal Interview with Author. Mamelodi, South Africa, May 2007.

Magagula, Katherine. Personal Interview with Author. Mamelodi, South Africa, July 2008.

Makope, Mabel. Testimony before the Truth and Reconciliation Commission Human Rights Violations Committee, Johannesburg, 30 April 1996.

Makope, Mabel. Personal Interview with Author. Mamelodi, South Africa, May 2007.

Mandela, Nelson. Long Walk to Freedom: The Autobiography of Nelson Mandela. Boston: Little Brown and Company, 1995.

Mashike, Lephophotho. "Age of Despair: The Unintegrated Forces of South Africa." African Affairs 107, no. 428 (2008): 433-53.

Mashike, Lephophotho. "'Some of Us Know Nothing except Military Skills': South Africa's Former Guerrilla Combatants." In State of the Nation: South Africa 2007, edited by Sakhela Buhlungu, John Daniel, Roger Southall and Jessica Lutchman, 351-78. Cape Town: HSRC Press, 2007.

Mbembe, Achille. "Necropolitics." Public Culture 15, no. 1 (2003): 11-40.

Meli, Francis. South Africa Belongs to Us: A History of the Anc. Harare: Zimbabwe Publishing House, 1988.

MKMVA, "Press Statement on the Mamelodi 10," 9 October 2008. Available at: http://www.cosatu.org.za/press/2008/oct/press22.htm. Accessed 30 March 2009. 
MKMVA, "Briefing on the Mamelodi 10," 10 October 2008. Available at: http://groups.google.com/group/COSATU-press/msg/19865005138f6ff4. Accessed 30 March 2009.

Ntuli, Maria. Personal Interview with Author. Mamelodi, South Africa, July 2008.

Ottaway, David. Chained Together. Mandela De Klerk, and the Struggle to Remake South Africa. New York: Times Books, 1993.

Pauw, Jacques. Into the Heart of Darkness: Confessions of Apartheid's Assassins. Johannesburg: Jonathan Ball, 1997.

Prinsloo, Hendrik Johannes. Testimony before the Truth and Reconciliation Commission Amnesty Hearings, Pretoria, 19 October 1999.

Sampson, Anthony. Mandela: The Authorised Biography. London: HarperCollins, 1999.

Sanford, Victoria. Buried Secrets: Truth and Human Rights in Guatemala. New York: Palgrave Macmillan, 2003.

Seekings, Jeremy. The Udf: A Story of the United Democratic Front in South Africa 1983-1991. Cape Town: David Philip, 2000.

Sefolo, Lizzie Thandi. Testimony before the Truth and Reconciliation Commission Human Rights Violations Committee, Johannesburg, 30 April 1996.

Sefolo, Lizzie. Personal Interview with Author. Mamelodi, South Africa, May 2007.

Sefolo, Lizzie. Personal Interview with Author. Mamelodi, South Africa, July 2008.

Sheehan, Helena. 2002. Interview with Jeremy Cronin. In, http://webpages.dcu.ie/ sheehanh/za/cronin02.html. (accessed 25 March, 2009).

Southall, Roger. "Introduction: The Anc State, More Dysfunctional Than Developmental?" In State of the Nation: South Africa 2007, edited by Sakhela Buhlungu, John Daniel, Roger Southall and Jessica Lutchman, 1-24. Cape Town: HSRC Press, 2007.

Sparks, Allister. Tomorrow Is Another Country: The inside Story of South Africa's Road to Change. New York: Hill and Wang, 1995.

Suttner, Raymond. "African National Congress (Anc): Attainment of Power, Post Liberation Phases and Current Crisis." Historia 52, no. 2 (2007): 1-46.

—. "Culture(S) of the African National Congress of South Africa [Anc]: Contribution of Exile and Prison Experiences." In WISER Seminar Series. Witwatersrand University, 2002. 
Team, Missing Persons Task. "Report for the Period 1 July 2005-30 June 2006." edited by National Prosecuting Authority Priority Crimes Litigation Unit, 2006.

Thomspon, Leonard. A History of South Africa, 3rd Edition. New Haven: Yale University Press, 2000.

van Vuuren, Paul. Testimony before the Truth and Reconciliation Commission Amnesty Hearings, Johannesburg, 21 October 1996.

Wagner, Sarah. To Know Where He Lies: Dna Technology and the Search for Srebrenica's Missing. Berkeley: University of California Press, 2008.

Waldmeir, Patty. Anatomy of a Miracle: The End of Apartheid and the Birth of the New South Africa. London: Viking, 1997.

Winter, Jay. "Forms of Kinship and Remembrance in the Aftermath of the Great War." In War and Remembrance in the Twentieth Century, edited by Jay Winter and Emmanuel Sivan, 40-60. Cambridge: Cambridge University Press, 1999.

Zunes, Stephen. "The Role of Non-Violent Action in the Downfall of Apartheid." The Journal of Modern African Studies 37, no. 1 (1999): 137-69. 